\title{
ABORTION IN NORTHERN IRELAND AND THE EUROPEAN CONVENTION ON HUMAN RIGHTS: REFLECTIONS FROM THE UK SUPREME COURT
}

\begin{abstract}
:
On 7 June 2018, the Supreme Court of the United Kingdom (UKSCt) issued its decision on, inter alia, whether Northern Ireland's near-total abortion ban was compatible with the European Convention of Human Rights (ECHR). This article critically assesses the UKSC's treatment of international law in this case. It argues that the UKSCt was justified in finding that Northern Ireland's ban on abortion in cases of rape, incest, and FFA was a violation of Article 8, but that the majority erred in its assessment of Article 3 ECHR and of the relevance of international law more generally.
\end{abstract}

\section{Keywords:}

Abortion; Northern Ireland; UK Supreme Court; European Convention on Human Rights; International Law; Right to Private and Family Life; Prohibition of Cruel, Inhumane and Degrading Treatment; Human Rights Act, Human Rights Committee.

\section{INTRODUCTION}

Northern Ireland has one of the strictest abortion frameworks in the world. Abortion is prohibited unless there is a risk to the life of the mother or a risk of serious long-term or permanent injury to her physical or mental health. ${ }^{1}$ This amounts to a near-total ban on abortion, including in cases of rape, incest, fatal fetal abnormality (FFA), and serious fetal abnormality. ${ }^{2}$ It also contrasts starkly to the applicable legal framework in England, Wales and Scotland where abortion has been legally available since 1967, and exemplifies Northern Ireland's devolved legislative powers. ${ }^{3}$ On 7 June 2018, the Supreme Court of the United Kingdom (UKSCt), issued its decision on two contentious issues: (i) whether Northern Ireland's abortion law was compatible with the European Convention of Human Rights (ECHR); and (ii) whether the Northern Ireland Human

\footnotetext{
${ }^{1}$ The applicable law is sections 58 and 59 of the Offences Against the Person Act 1861, and section 25(1) of the Criminal Justice Act (NI) 1945. The Abortion Act 1967 does not extend to Northern Ireland.

${ }^{2}$ FFA is where the fetus is likely to die before birth or shortly after, whereas serious fetal abnormality is an abnormality which is serious but not immediately life threatening per se.

$3 \mathrm{~J}$ Thomson, Explaining gender equality difference in a devolved system: The case of abortion law in Northern Ireland (2016) 11(3) Politics, Languages \& International Studies 371.
} 
Rights Commission (NIHRC) had standing to bring such proceedings. ${ }^{4}$ This was the first time the UKSCt has considered the substantive compatibility of restrictions on abortion in Northern Ireland with the ECHR. ${ }^{5}$ The NIHRC brought the challenge by presenting four scenarios, rather than identifiable complainants, arguing that denial of abortion to women in Northern Ireland generally in cases of rape, serious fetal abnormality, FFA, and pregnancy as a result of rape and incest violated Article 3 and Article 8 ECHR. The UKSCt held that the NIHRC did not have standing and accordingly that the UKSCt had no jurisdiction to make a declaration of incompatibility with the ECHR. ${ }^{6}$ Nonetheless, the judges gave their views on how they would have decided if the UKSCt were able to make such a declaration. ${ }^{7}$

The majority (Lord Mance, Lord Kerr, Lord Wilson, and Lady Hale) found that Northern Ireland's abortion law violated Article 8 of the ECHR (the right to respect for private and family life) insofar as it prohibits abortion in cases of rape, incest and FFA, ${ }^{8}$ but not in cases of serious fetal abnormality. ${ }^{9}$ Lord Kerr and Lord Wilson also held that Northern Ireland's abortion law violated the prohibition of inhuman and degrading treatment, guaranteed by Article 3 ECHR. ${ }^{10}$

Although the primary substantive issue before the UKSCt was the relationship between Northern Irish law and the ECHR, the majority noted that the ECHR must be interpreted in light of other international treaties to which the UK is a party. ${ }^{11}$ This article will critically assess whether this goal was achieved. It will argue that the UKSCt was justified in finding that Northern Ireland's ban on abortion in cases of rape, incest, and FFA was a violation of Article 8, but that the majority erred in its assessment of Article 3 ECHR and of the relevance of international law more generally. We argue that the

${ }^{4}$ In the Matter of an Application by the Northern Ireland Human Rights Commission for Judicial Review (Northern Ireland) [2018] UKSC 27.

5 In 2017 the UKSCt considered whether funding for travel for abortion services should be provided to women in Norther Ireland, $R$ (on the application of $A$ and B) $v$ Secretary of State for Health [2017] UKSC 41.

${ }_{7}^{6}$ A declaration of incompatibility was sought under section 4 of the Human Rights Act 1998.

${ }^{7}$ Although the appropriateness of making obiter comments of this nature may be questioned, this issue is outside the scope of this article.

${ }^{8}$ Lady Black agreed with this holding in cases of FFA.

${ }^{9}$ Lord Mance, Hale, and Lord Kerr (with whom Lord Wilson agreed). Lord Reed (with whom Lord Lloyd Jones agreed) did not find any violations of Art 8 and instead would leave this as an issue for Parliament. Lady Black agreed with Lord Reed in cases other than FFA.

${ }^{10}$ Lord Reed and Lord Lloyd-Jones held that the law is not incompatible with either Art 8 or Art 3.

${ }^{11}$ Lady Hale para 5; Lord Mance, para 101; Lord Kerr (with whom Lord Wilson agreed) para 328. The UK is a party to the following treaties which were relevant to the subject matter before the UKSCt: 1984 Convention against Torture 1465 UNTS 85; 1966 International Covenant on Economic, Social, and Cultural Rights; 1966 International Covenant on Civil and Political Rights 999 UNTS 171; 1989 Convention on the Rights of the Child 1577 UNTS 3; 1979 Convention on the Elimination of all forms of Discrimination against Women 1249 UNTS 13; 2008 Convention on the Rights of Persons with Disabilities 2515 UNTS 3. 
UKSCt should have identified that the jurisprudence of the ECHR on Article 3 has broadened in recent years and thus the UKSCt should have found that Northern Ireland's near-total ban on abortion was a violation of Article 3. We also show that although non-binding, there are persuasive reasons why the UN Human Rights Committee's $(H R C)^{12}$ views should have been taken into account by the UKSCt in interpreting the scope of Article $3 \mathrm{ECHR}$. We therefore argue that by not finding a violation of Article 3 at least in cases of incest, rape, and FFA, the UKSCt missed a valuable opportunity to give a full reflection of the incompatibility of Northern Ireland's abortion law with the ECHR and with international law.

This piece is the first to analyse the UKSCt's treatment of international law in this case, and the arguments made are significant for three main reasons. First, in its decision, the UKSCt explicitly stated that should an individual who is a victim of rape, incest, or whose pregnancy has a FFA take a future case challenging Northern Ireland's abortion law, the Court would likely find in their favour. As such, the UKSCt has invited future litigation on this issue. When these cases come before the courts, the previous views of the UKSCt on the relationship between Northern Ireland's abortion legislation with the ECHR will not be binding but rather of persuasive authority only. This is because the views of the UKSCt in this respect were obiter. Thus, in future cases, a court will be free to make its own determination on the relationship between the ECHR and Northern Ireland's abortion law. In doing so, it is hoped that our analysis on the scope of Article $8 \mathrm{ECHR}$ and on the applicability of Article $3 \mathrm{ECHR}$ in this context could be of use to both courts and advocates.

Secondly, we argue that applicants in such circumstances should be encouraged to bring challenges based on Article 3 , and that court considering future challenges should go further than the UKSCt and find a violation of Article 3 and Article 8 (instead of simply a violation of Article 8). Finding a violation of both Article 3 and Article 8 is significant because a violation of Article 3 is one of the most serious human rights violations, evident by the fact that it is an absolute right with no margin of appreciation. ${ }^{13}$ Such a finding would add greater pressure for Northern Ireland to engage in legislative change in this area. This is important because even if a declaration of incompatibility is

\footnotetext{
12 The HRC is a quasi-judicial international committee of independent experts that monitors the implementation of the ICCPR by its States Parties. The HRC was established by Art 28 of the ICCPR. It can receive communications from individuals against States Parties to the First Optional Protocol (pursuant to Art 1 of Optional Protocol 1) and the HRC can forward its 'views' to the State Party concerned and to the individual. These views are not binding. However, as the members of the HRC are experts in international law, and as they are interpreting the ICCPR itself, their views are highly persuasive and are seen as authoritative interpretations of the ICCPR. Art 38(1)(d) of the Charter of the United Nations and Statute of the International Court of Justice 1 UNTS 16 also provides that the views of experts are a subsidiary source of international law.

${ }^{13}$ See section III.
} 
made under UK law there is no legal obligation on the Government to take remedial action, and the decision as to whether the laws are changed rests with Parliament. ${ }^{14} \mathrm{~A}$ further difficulty in this context is that the Northern Ireland Assembly is currently suspended, thus there is no way for Northern Ireland to reform its abortion laws until the Assembly comes back into operation. ${ }^{15}$ If the UKSCt were to find a breach of Article 3 alongside Article $8 \mathrm{ECHR}$, this would put the Northern Ireland Assembly under more pressure to resolve the Assembly and once resolved, to amend Northern Ireland's abortion laws. Moreover, it is envisaged that the arguments in this piece can provide guidance for legislators in Northern Ireland should they decide to change the law.

Finally, Lord Kerr noted that he would not engage with the views of the HRC because 'the status of those decisions and their relevance in domestic proceedings.... are far from straightforward subjects. ${ }^{, 16}$ This article clarifies the relationship between international law and domestic law, and should thus be of guidance for a court or advocates wishing to draw on international law as a persuasive source in future cases.

The article will proceed as follows. Section II will show why the suffering experienced by women denied abortions in cases of FFA, rape and incest should be recognised as human rights violations. Sections III and IV will focus on the UKSCt's treatment of Article 8 and $3 \mathrm{ECHR}$, respectively. Section $V$ will examine the UKSCt's treatment of international law more generally, and section VI will conclude.

\section{DENIAL OF ABORTION ACCESS AS A HUMAN RIGHTS VIOLATION}

There is consensus in literature that the denial of abortion entails significant hardship and suffering, particularly where abortion is heavily restricted and where attempting to access abortion for any reason is highly stigmatized. ${ }^{17}$ Denial of abortion is seen by

\footnotetext{
${ }^{14}$ Ministry for Justice, Responding to Human Rights judgments, Report to the Joint Committee on Human Rights on the Government's response to Human Rights judgments 201617 (December 2017) available at https://assets.publishing.service.gov.uk/government/uploads/system/uploads/attachment data/file/66944 9/responding to human rights judgments 2016-17-print.pdf p. 4-5

15 'UK government calls for Northern Ireland to consider abortion reforms' ( $5^{\text {th }}$ June 2018) RTE News available at https://www.rte.ie/news/uk/2018/0605/968195-oapa/ A last resort would be to encourage the UK Parliament to repeal relevant sections of the OAPA. This would make abortion illegal and force the Northern Ireland Assembly to act. See https://www.thejournal.ie/uk-debate-abortion-northern-ireland4053119-Jun2018/

${ }_{17}^{16}$ Para 330.

17 A Zureick, '(En)gendering Suffering: Denial of Abortion as a Form of Cruel, Inhuman, or Degrading Treatment' (2015) 38(1) Fordham International Law Journal 99; K McNeilly, C Pierson, and F Bloomer (2016), 'Moving Forward From Judicial Review on Abortion in Situations of Fatal Foetal Abnormality and Sexual Crime: The Experience of Health Professionals. Queen's University Belfast at 6; F Bloomer, $\mathrm{F}$ and Hoggart, L (2016) Abortion Policy - Challenges and Opportunities. Briefing Paper, Knowledge Exchange Seminar Series. RAISE/ NI Assembly; Abortion Worldwide: Uneven Progress and Unequal Access'
} 
many as a violation of pregnant woman's right to autonomy, self-determination, and bodily integrity. ${ }^{18}$ As Margaret Olivia Little argues:

'To be pregnant is to be inhabited. It is to be occupied. It is to be in a state of physical intimacy of a particularly thorough-going nature. The fetus intrudes on the body massively; whatever medical risks one faces or avoids, the brute fact remains that the fetus shifts and alters the very physical boundaries of the woman's self. ${ }^{19}$

Refusing an abortion to a woman who requests one forces her to continue the pregnancy, entails significant physical changes to her body, creates potential medical risks, and fundamentally challenges her bodily autonomy. For these reasons, some argue that abortions should be made available to all women who request them and that a distinction between particular categories such as FFA etc should not be drawn. ${ }^{20}$ We agree with this position, but we accept that at the time of writing, international law only recognizes a right to abortion in in cases of FFA, and where the pregnancy is a result of rape or incest. $^{21}$

There are good reasons why international law recognizes that States must provide abortion access in these exceptional circumstances. The three options facing such women- terminating the pregnancy illegally, travelling abroad to terminate the pregnancy, or being forced to carry the pregnancy to term - can further exacerbate their severe suffering and humiliation contingent from their circumstances. The first option procuring an illegal abortion (for example, by purchasing pills on the internet) - could expose such a woman to risks to her life and/or health as it would be carried out without medical supervision. ${ }^{22}$ She is likely to fear seeking counselling and/or aftercare if there are any complications. She would also have to undertake the risks of criminal charges

(2017) Guttamacher Institute https://www.guttmacher.org/sites/default/files/report_pdf/abortion-worldwide2017.pdf.

18 J Jarvis Thomson, 'A defence of abortion' (1971) 1 Philospohy and Public Affaors 47; E Jackson, 'Abortion, Autonomy and Prenatal Diagnosis' (2000) 9(4) Social \& Legal Studies 467-494; E Jackson,'Abortion: medical paternalism or patient autonomy?' in: E Lee (ed.) Abortion: Whose Right? Debating matters. (Hodder and Stoughton, London, UK, 2002); S Sheldon, 'The Decriminalisation of Abortion: An Argument for Modernisation' (2016) 36(2) Oxford Journal of Legal Studies 334-365.

${ }^{19}$ MO Little, 'Abortion, intimacy and the duty to gestate' (1999) 2 Ethical Theory and Moral Practice 295311.

20 IG Cohen, Are all abortions equal? Should there be exceptions to the criminalization of abortion for rape and incest? (2015) 43(1) Journal of Medical Ethics 87; S Sheldon and S Wilkinson, 'Termination of Pregnancy for Reason of Foetal Disability: Are There Grounds for a Special Exemption in Law?' (2001) 9 Medical Law Review 85.

${ }^{21}$ A Zureick, '(En)gendering Suffering: Denial of Abortion as a Form of Cruel, Inhuman, or Degrading Treatment' (2015) 38(1) Fordham International Law Journal 99.

22 'Abortion Worldwide: Uneven Progress and Unequal Access' (2017) Guttamacher Institute https://www.guttmacher.org/sites/default/files/report_pdf/abortion-worldwide-2017.pdf 28- 33. 
being brought against her, ${ }^{23}$ and the corresponding lack of information available and stigma associated with carrying out an illegal act. The second option - procuring an abortion abroad - could result in significant cost and difficulties in securing time off from employment and/or caring responsibilities. She would have to undergo an invasive medical procedure in a foreign environment, possibly without a support structure; and may have to leave the fetus' remains behind and secure transport of the remains at additional costs/stress. ${ }^{24}$ Similarly, she is likely to suffer the stigma associated with the criminalisation of abortion, and the consequent lack of information, counselling and/or aftercare. The third option of carrying a pregnancy to term against her will would also likely result in 'intense physical and mental suffering'. ${ }^{25}$ Those whose pregnancies have a FFA would have to carry the pregnancy to term knowing the fetus would not survive. This could make the pregnancy more traumatic and because the fetus will die either before or shortly after birth, trying to vindicate the life of the fetus is futile. ${ }^{26}$ Where the pregnancy is a result of rape, prohibiting abortion is likely to exacerbate suffering for women denied an abortion as the pregnancy and the potential child may act as a reminder of the rape. ${ }^{27}$ In cases of incest, it would be 'plainly humiliating, ${ }^{28}$ to require a woman to continue a pregnancy that she considers 'abhorrent' ${ }^{29}$ to term.

\footnotetext{
${ }^{23}$ Abortion is a criminal offence in Northern Ireland under sections 58 and 59 of the Offences Against the Person Act 1861, punishable by up to life imprisonment. Women procuring an abortion and those who assist them are potentially criminally responsible.

${ }^{24} \mathrm{~K}$ McNeilly, C Pierson, and F Bloomer, 'Moving Forward From Judicial Review on Abortion in Situations of Fatal Foetal Abnormality and Sexual Crime: The Experience of Health Professionals. (Queen's University Belfast, 2016) 6 available at https://pure.qub.ac.uk/portal/files/127528554/HealthcareProfessionalsRoundtableReport 090916.pdf ; F Bloomer, and L Hoggart, 'Briefing Paper, Knowledge Exchange Seminar Series -Abortion Policy Challenges and Opportunities' (RAISE/ Norther Ireland Assembly, 2016) available at http://www.niassembly.gov.uk/globalassets/documents/raise/knowledge exchange/briefing papers/series 5/dr-bloomer-and-dr-hoggart-version-2.pdf

${ }^{25}$ Committee on the Elimination of Discrimination Against Woman, 'Report of the inquiry concerning the United Kingdom of Great Britain and Northern Ireland under Art 8 of the Optional Protocol to the Convention on the Elimination of All Forms of Discrimination against Women' CEDAW/C/OP.8/GBR/1 (19 July 2017); Council of Europe, Commissioner for Human Rights, 'Issue Paper: Women's sexual and reproductive health and rights in Europe' (December, 2017) < https://rm.coe.int/women-s-sexual-andreproductive-health-and-rights-in-europe-issue-pape/168076dead>; Nils Muižnieks, Commissioner for Human Rights of the Council of Europe, 'Report following his visit to Ireland 22-25 November 2016' (27 March 2017) CommDH (2017), para 91.

${ }^{26}$ F De Londras and M Enright, Reforming Irish Abortion Law (2018), chapter 2; F de Londras, 'Fatal Fetal Abnormality, Irish Constitutional Law and Mellet v Ireland' 24(4) Medical Law Review 591, 595 (2016), J Schweppe and E Spain, 'When is a Foetus not an Unborn? Fatal Foetal Abnormalities and Article 40.3.3 3' (3) Irish Journal of Legal Studies 92 (2013), E Barrington, 'Submission to Citizens' Assembly, Article 40.3.3 of the Constitution and Fatal Foetal Abnormalities' (January 2017) para 3.3, available at https://www.citizensassembly.ie/en/Meetings/Eileen-Barrington-Paper.pdf.

27 See comments of Prof Ruth Halperin-Kaddari in Press Release of UN Office of the High Commissioner, 'UK violates women's rights in Northern Ireland by unduly restricting access to abortion UN experts' available at https://www.ohchr.org/en/NewsEvents/Pages/DisplayNews.aspx?NewsID=22693\&LangID=E
} 
Furthermore, there is no consensus on where life begins and States are given a margin of appreciation under the ECHR regarding the legal status of the fetus. ${ }^{30}$ Thus the ECHR does not preclude granting abortion access and instead it limits the extent to which any perceived 'right' of the fetus can trump the rights of pregnant women.

There are therefore convincing reasons why States are obliged to provide for abortion access at least in cases of FFA, rape, and incest. The following sections will address whether the UKSCt correctly assessed the compatibility of these international law obligations with Northern Ireland's restrictive abortion framework.

\section{ARTICLE 8 OF THE EUROPEAN CONVENTION ON HUMAN RIGHTS}

Article 8(1) of the ECHR provides that 'everyone has the right to respect for his private and family life. ${ }^{, 31}$ It is common ground that prohibiting abortion is an interference with a person's private and family life. ${ }^{32}$ However, the key legal question is whether such interference is justified under the terms of Article 8 (2) ECHR as being 'in accordance with the law and [...] necessary in a democratic society [...] for the protection of health or morals, or for the protection of the rights and freedoms of others'. As noted, the majority found Northern Irish law to be in violation of Article 8 but for different reasons and with some disagreement over what circumstances would be a violation of Article 8 . Lord Mance, Lord Kerr, Lord Wilson and Lady Hale held that Northern Irish law is incompatible with Article 8, insofar as it prohibits abortion in cases of rape, incest and FFA; Lady Black agreed with the holding for cases of FFA only; and Lord Reed and Lord Lloyd-Jones held that the law is not incompatible with Article 8.

The following key reasons were given by the majority. In respect of FFA the Court acknowledged the distress caused to women who are denied abortion access in these circumstances. Lady Hale indicated that there was no 'community interest in obliging

\footnotetext{
${ }^{28}$ Lord Kerr (with whom Lord Wilson agreed), para 237.

${ }^{29}$ Lord Kerr (with whom Lord Wilson agreed), para 242.

${ }^{30}$ Vo v France (2004) 40 E.H.R.R. 12. See also: Paton v United Kingdom [1981] 3 E.H.R.R. 408; RH v Norway (Admissibility) (App. No.17004/90), Eur.Comm.H.R. May 19, 1992; Boso v Italy (App.No.50490/99), Eur.Comm.H.R. September 5, 2002. See also, S Palmer, 'Abortion and human rights' (2014) 4 European Human Rights Law Review 596; R Scott, 'The English Fetus and the Right to Life' (2004), European Journal of Health Law, 11(4), 347-364.

${ }^{31}$ Art 8(2) provides that there shall be no interference by a public authority with the exercise of this right except such as is in accordance with the law and is necessary in a democratic society in the interests of national security, public safety or the economic well-being of the country, for the prevention of disorder or crime, for the protection of health or morals, or for the protection of the rights and freedoms of others.

${ }^{32}$ Lady Hale, para 19.
} 
the woman to carry the pregnancy to term if she does not wish to do so. There is no viable life to protect. ${ }^{, 33}$ Lord Mance and Lord Kerr (with whom Lord Wilson agreed) stated that denying abortion in such cases was disproportionate to the aim of protecting unborn life. Lord Mance noted that the current law forces women to carry a fetus to term regardless of the circumstances and this fails to take account of the personal autonomy and freedom of women, values which underpins Article $8 .^{34}$ Similarly Lord Kerr (with whom Lord Wilson agreed) stated that:

Put in stark terms, if the fetus has little hope of survival, can it be said that requiring the mother to carry it to term is the least intrusive means of achieving the aim of protecting the unborn child who does have a hope of survival? Clearly not. ${ }^{35}$

Lady Black also joined the majority in finding a violation on this ground. She noted that where there is a FFA there is no life outside the womb to protect and in her view denial of an abortion in such cases is an intrusion upon the autonomy and suffering of the pregnant woman which cannot be justified. ${ }^{36}$ Moreover, FFA is often diagnosed late in pregnancy and this makes the process of arranging travel for an abortion even more demanding, due to the limited time available. ${ }^{37}$

The majority (Lord Mance, Lord Kerr, Lord Wilson and Lady Hale) concluded that denying access to abortion in cases of rape was also a violation of Article 8. Lord Mance acknowledged the anguish which may arise from pregnancy following rape, which does not end on the birth of the child but continues with potential responsibility for that child for life. Causing a woman to become pregnant against her will is a grave intrusion on bodily integrity, and Lord Mance stated the law should not further perpetuate a woman's suffering. ${ }^{38}$ The fact that a woman could travel outside the jurisdiction for an abortion did not justify the prohibition of abortion in such cases. ${ }^{39}$

The majority also held that denial of abortion in cases of incest was a violation of Article $8 .^{40}$ Lord Mance indicated that many typical cases of abortion arising in cases of incest involve exploitative relationships with young or younger female relatives, which may often also be as a result of rape. The suffering to a woman is evident and the 'agony of having to carry a child to birth, and to have a potential responsibility for, and lifelong relationship with, the child thereafter, against the mother's will, cannot be

\footnotetext{
33 Lady Hale, para 28.

${ }^{34}$ Lord Mance, para 125.

${ }^{35}$ Lord Kerr, para 284.

${ }^{36}$ Lady Black, para 371.

${ }^{37}$ Lady Black, para 371.

${ }^{38}$ Lord Mance, para 127.

${ }^{39}$ Lord Mance, para 127.

${ }^{40}$ Lady Hale, Lord Mance, and Lord Kerr (with whom Lord Wilson agreed).
} 
justified. ${ }^{41}$ Lady Hale stated that abortion where pregnancy results from rape or incest, were situations where the 'autonomy rights of the pregnant woman should prevail over the community interests in the continuation of pregnancy'. ${ }^{42}$

The majority did not find that denial of abortion in cases of serious (as opposed to fatal) abnormality was a breach of Article $8 .{ }^{43}$ Lord Mance stated that a disabled child should be treated as having the same worth as a non-disabled child, and noted the concerns of the UN Committee on Rights of Persons with Disabilities around providing terminations in cases of fetal abnormality. ${ }^{44}$

We welcome these findings in respect of Article 8 because the approach taken by the UKSCt is in line with its obligations under the ECHR. Although the ECtHR has generally given deference to States in the abortion context, it has not in any way precluded domestic courts from making findings of violations. This is because the ECtHR has generally adopted a margin of appreciation for States with strict abortion regimes. ${ }^{45}$ The margin of appreciation refers to the discretion or scope for manoeuvre bestowed upon Contracting States of the ECHR in fulfilling their obligations under the Convention. ${ }^{46}$ The rationale for this approach is that in some contexts (particularly where no consensus amongst Member States is evident), Contracting States should be given leeway because:

By reason of their direct and continuous contact with the vital forces of their countries, State authorities are in principle in a better position than the international judge to give an opinion on the exact content of these requirements as well as on the 'necessity' of a 'restriction' or 'penalty' intended to meet them. ${ }^{47}$ [Emphasis added]

The margin of appreciation for States in relation to Article 8 in cases where abortion is prohibited was accepted by the ECtHR in $A, B, C v$ Ireland where the ECtHR stated that it is "not possible to find in the legal and social orders of the Contracting

\footnotetext{
${ }^{41}$ Lord Mance, para 132.

${ }^{42}$ Lady Hale, para 27.

${ }^{43}$ Lord Mance, Hale, and Lord Kerr (with whom Lord Wilson agreed). Lord Reed with whom Lord Lloyd Jones agreed did not find any violations of Art 8 and instead would leave this as an issue for parliament. Lady Black agreed with Lord Reed in cases outside of fatal fetal abnormality.

${ }^{44}$ Lord Mance, para 133.

${ }^{45}$ See $A, B$ and $C$ v Ireland [2010] ECHR 2032.

${ }^{46} \mathrm{H}$ Yourow, The Margin of Appreciation Doctrine in the Dynamics of European Human Rights Jurisprudence (Kluwer Academic Publishers 1996), 13; See also M R Hutchinson, 'The Margin of Appreciation in the European Court of Human Rights' (1999) 48(3) ICLQ 638, 647; R Nigro, 'The Margin of Appreciation Doctrine and the Case-Law of the European Court of Human Rights on the Islamic Veil' (2010) 11 HR Rev 531.

${ }^{47}$ Handyside $v$ United Kingdom (Application no. 5493/72) Judgment of $7^{\text {th }}$ December, 1976, para 48.
} 
States a uniform European conception of morals including on the question of when life begins $^{48}$ and national authorities were held to be best placed to decide upon such issues. Accordingly, in finding a violation of Article 8, the UKSCt went beyond the usual reluctance of the ECtHR to find a violation of this right in the abortion context. ${ }^{49}$ However, this article argues that in doing so the UKSCt's position nonetheless conforms with that of the ECtHR because the ECtHR has left it open to domestic courts to find a violation the Convention in respect of strict abortion regimes. Unlike the ECtHR, a national court:

[...] is not constrained by the margin of appreciation, but rather must apply Convention rights, and their limitations, as part of domestic law. In doing so they can, of course, show judicial deference to the national Parliament or executive; but must judge whether the restriction is compatible with the rights now contained in domestic law. ${ }^{50}$

As Gerards states, it would be a misinterpretation of the margin of appreciation doctrine if national courts simply automatically translated a wide margin of appreciation to deferential judicial review at national level. Instead, national courts have a 'shared responsibility' with the ECtHR and must exercise a supervisory role at a domestic level based on the context which arises at the State level. ${ }^{51}$ It was therefore appropriate for the UKSCt to find a violation of Article 8, even though the ECtHR has generally granted a margin of appreciation on this issue. Moreover, there is a growing recognition in international law of the right to abortion access in cases of rape, incest, FFA and where the life of the mother is in danger. ${ }^{52}$

\footnotetext{
${ }^{48} A, B$ and C v Ireland [2010] ECHR 2032, para 22.

49 S Foster, Case Comment: In the matter of an application by the Northern Ireland Human Rights Commission for Judicial Review: abortion - declarations of incompatibility - right to private life - inhuman or degrading treatment or punishment - locus standi - Cov. L.J. 2018, 23(1), 117-122; A Davies, 'The UKSCt Decision on Abortion in Northern Ireland: A Pyrrhic Defeat?' Oxford Human Rights Hub http://ohrh.law.ox.ac.uk/the-uk-supreme-court-decision-on-abortion-in-northern-ireland-a-pyrrhic-defeat/

${ }^{50} \mathrm{~S}$ Foster, In the matter of an application by the Northern Ireland Human Rights Commission for Judicial Review: abortion - declarations of incompatibility - right to private life - inhuman or degrading treatment or punishment - locus standi (2018) Coventry Law Journal 117, 121.

$51 \mathrm{JH}$ Gerards, The European Court of Human Rights and the National Courts: Giving Shape to the Notion of 'Shared Responsibility' in JH Gerards \& JWA Fleuren (eds.), Implementation of the European Convention on Human Rights and of the judgments of the ECtHR in national case law. A comparative analysis (Antwerp: Intersentia 2014) at 31, 32.

52 ICCPR Concluding observations on the fourth periodic report of Ireland; United Nations Economic and Social Council E/C.12/IRL/CO/3 Distr.: General 8 July 2015 , Committee on Economic, Social and Cultural Rights Concluding observations on the third periodic report of Ireland. CEDAW/C/50/D/22/2009, 4 November 2011; LC v Peru Communication No. 22/2009. United Nations Economic and Social Council E/C.12/IRL/CO/3 Distr.: General 8 July 2015, Committee on Economic, Social and Cultural Rights Concluding observations on the third periodic report of Ireland. Concluding observations on the 7th and 8th periodic reports of Peru CEDAW/C/IRL/CO/6-7; C Zampas and JM Gher, 'Abortion as a Human Right
} 


\section{ARTICLE 3 OF THE EUROPEAN CONVENTION ON HUMAN RIGHTS}

The majority of the UKSCt did not find that Northern Ireland's abortion framework breached Article 3 ECHR. Article 3 provides that 'no one shall be subjected to torture or to inhuman or degrading treatment or punishment.' The ECtHR has held on numerous occasions that the alleged ill-treatment must attain a minimum level of severity to fall within the scope of Article 3. The assessment of this threshold is relative and depends on all the circumstances of the case, such as the duration of the treatment and its physical or mental effects and the sex, age and state of health of the victim. ${ }^{53}$ The ECtHR considers treatment to be 'inhuman' when it was 'premeditated, [...] applied for hours at a stretch and caused either actual bodily injury or intense physical or mental suffering'. ${ }^{54}$ Treatment is considered to be 'degrading" when it humiliates or debases an individual, showing a lack of respect for, or diminishing, his or her human dignity, or arouses feelings of fear, anguish or inferiority capable of breaking an individual's moral and physical resistance. ${ }^{55}$ It may suffice that the victim is humiliated in his or her own eyes, even if not in the eyes of others. ${ }^{56}$

Unlike Article 8, Article 3 ECHR protects an absolute right. ${ }^{57}$ It must be upheld even 'in times of war or other public emergency threatening the life of a nation'. ${ }^{58}$ No margin of appreciation applies, and States cannot justify any limitations or restrictions of

- International and Regional Standards' (2008) 8(2) Human Rights Law Review 249. See also: A McMahon and B Ní Ghráinne, 'After the Eighth: Ireland, Abortion and International Law' available at https://papers.ssrn.com/sol3/papers.cfm?abstract id=3256317.; and views of Lord Mance, para 118-121.

${ }_{53}$ Kudła v Poland App no 30210/96 (ECHR, 26 October 2000) para 91.

${ }^{54}$ Kudła $v$ Poland App no 30210/96 (ECtHR, 26 October 2000) para 92.

${ }^{55}$ Kudła v Poland App no 30210/96 (ECHR, 26 October 2000)para 92; Pretty $v$ the United Kingdom App no. 2346/02 (ECHR, 29 April 2002) para 52.

${ }_{57}^{56}$ Tyrer $v$ The United Kingdom App no 5856/72 (ECHR, 15 March 1978) para 32.

$57 \mathrm{~N}$ Mavronicola, 'Is the Prohibition Against Torture and Cruel, Inhuman and Degrading Treatment Absolute in International Human Rights Law? A Reply to Steven Greer' (2017) 17(3) Human Rights Law Review 479; N Mavronicola, 'What Is an Absolute Right: Deciphering Absoluteness in the Context of Article 3 of the European Convention on Human Rights' 12(4) Human Rights Law Review 723; D Feldman, Civil Liberties and Human Rights in England and Wales (2nd edn, Oxford University Press 2002) 242; N Mavronicola, 'Crime, Punishment and Article 3 ECHR: Puzzles and Prospects of Applying an Absolute Right in a Penal Context' (2015) 15(4) Human Rights Law Review 721. For a contrary opinion, see S Greer, 'Is the Prohibition Against Torture, Cruel, Inhuman and Degrading Treatment Really "Absolute" in International Human Rights Law? A Reply to Griffin and Mavronicola' (2018) 18(2) Human Rights Law Review 297; S Greer, 'Is the Prohibition against Torture, Cruel, Inhuman and Degrading Treatment Really 'Absolute' in International Human Rights Law?' (2015) 15(1) Human Rights Law Review 101; S Greer, 'Should Police Threats to Torture Suspects Always be Severely Punished? Reflections on the Gafgen Case' (2011) 11 Human Rights Law Review 67.

${ }^{58}$ Art 15(1) ECHR. 
rights falling under this Article. ${ }^{59}$ Once an act is determined to constitute torture, or inhuman, or degrading treatment, States are held to be in violation of the ECHR.

We argue that the UKSCt was correct in finding that the ban of abortion in respect of serious fetal abnormality did not violate Article 3 . This is because there is no consensus under international law at the time of writing on whether there is a right to an abortion in such circumstances, a point returned to in part IV. Nonetheless, we argue that the Court was incorrect in finding that the prohibition of abortion in cases of rape, FFA, or incest did not violate Article 3 . In the following paragraphs, we set out six key reasons why the UKSCt's analysis was lacking in this respect, and make suggestions as to how these issues should be dealt with in the likely event of future litigation.

\section{A. Failure to Consider the Effects of the Law in Relation to Article 3}

Lady Hale stated that she had 'no doubt' that the risk of prosecution of women who had an illegal abortion and the fact that many women had to travel to Great Britain to have an abortion constituted 'treatment' of the State for the purposes of Article 3 ECHR. None of the judges contested this point. However, many judges found that Northern Ireland's abortion framework did not violate Article $3 \mathrm{ECHR}$ because not every woman who is denied an abortion in the circumstances before the UKSCt (in cases of FFA, or the where pregnancy is due to rape or incest) would suffer a violation of Article 3 ECHR. ${ }^{60}$ Yet, none of the judges who held that Article 3 was not violated, or who refused to rule on this point, considered why the Article 3 threshold was not met. It would have been preferable had the judges considered that all women who become pregnant as a result of rape or incest, or who have had a diagnosis of FFA and are denied access to abortion share certain characteristics which could amount to circumstances sufficient to meet the threshold for Article 3 - the suffering of women in such cases has been explained above in section II.

It is curious that some of the judges in the majority found the suffering of women in the circumstances before the court relevant for the Article 8 analysis, but did not explore these circumstances in relation to Article 3 . For example, in finding that the ban on abortion in cases of rape, FFA, and incest violated Article 8, Lord Mance referred to a number of personal stories of women who had been affected by the ban and engaged in a detailed examination of their 'distressing' circumstances. ${ }^{61} \mathrm{He}$ referred to the 'substantial and 'potentially long-term' ${ }^{62}$ 'stress', ${ }^{63}$ 'trauma', ${ }^{64}$ 'anguish', ${ }^{65}$ and

\footnotetext{
${ }^{59}$ Ireland $v$ United Kingdom App no 5319/71 (ECHR, 1 January 1978).

${ }^{60}$ Lady Hale para 34; Lord Mance para 102; Lady Black agreed with Lord Mance at para 367.

${ }^{61}$ Para 74.

${ }^{62}$ Para 126.

${ }^{63}$ Para 126.

${ }^{64}$ Para 126.
} 
'psychological injury'66 suffered by such women, as well as the 'stress, indignity, and expense, ${ }^{67}$ of arranging for an abortion elsewhere. ${ }^{68}$ In respect of pregnancies with FFA, he noted the 'appalling prospect of having to carry a fatally doomed foetus to term, irrespective of such associated physical risks. ${ }^{69}$ Where pregnancy was the product of rape, he noted 'the additional burden and torment of being expected to carry to birth and thereafter to live with a baby" ${ }^{70}$ and noted that 'this is a situation where the law should protect the abused woman, not perpetuate her suffering. ${ }^{71} \mathrm{He}$ also noted that the most typical cases of pregnancies due to incest involved 'exploitative relationships with young or younger female relatives ${ }^{, 72}$ and that 'the agony of having to carry a child to birth, and to have a potential responsibility for, and lifelong relationship with, the child thereafter, against the mother's will, cannot be justified. ${ }^{73}$ Lady Hale made similar observations. ${ }^{74}$ It is particularly noteworthy that Lady Hale cited a report from the Committee on the Elimination of Discrimination against Women (CEDAW) ${ }^{75}$ as authority that the suffering imposed by Northern Ireland's law constituted a breach of the right to privacy, ${ }^{76}$ but neglected to note that the exact same report stated that the law also constituted a violation of the prohibition of cruel, inhuman, and degrading treatment. ${ }^{77}$ It is therefore clear that the UKSCt was well-aware of the suffering imposed by Northern Ireland's abortion legislation, but neglected to engage with this issue. It is particularly noteworthy that the UKSCt did not refer to the ECtHR's well-established position that psychological distress and denial of medical treatment can lead to a violation of Article $3,{ }^{76}$ as well as the case-law analysed in section $C$ below which takes into account the vulnerability of the applicant when assessing a violation of Article 3. It would have been prudent to also consider relevant international law jurisprudence on the prohibition of inhuman and degrading treatment, a point which will be returned to in Section IV. Thus, by neglecting to engage with the effect Northern Ireland's abortion legislation has on women in the circumstances before the Court, by ignoring relevant jurisprudence, and by failing to

\footnotetext{
${ }^{65}$ Para 127.

${ }^{66}$ Para 127.

${ }^{67}$ Para 126.

${ }^{68}$ Lord Mance, paras 85-90.

${ }^{69}$ Para 123.

${ }_{71}^{70}$ Para 127.

${ }^{71}$ Para 127.

${ }^{72}$ Para 132.

${ }^{73}$ Para 132.

${ }^{74}$ She referred to referred to the 'double invasion' of the autonomy of a woman who did not consent to becoming pregnant, nor to the act of intercourse which made her pregnant. She also noted that pregnancies as a result of rape and incest were 'situations in which the autonomy rights of the pregnant woman should prevail over the community's interest in the continuation of the pregnancy.' Para 25.

${ }^{75}$ Report of the inquiry concerning the United Kingdom of Great Britain and Northern Ireland under Art 8 of the Optional Protocol to the Convention on the Elimination of All Forms of Discrimination against Women, CEDAW/C/OP.8/GBR/1, published 23 February 2018,

${ }^{76}$ Para 27.

77 The CEDAW committee referred to the prohibition of cruel, inhuman, and degrading treatment as set out in the ICCPR. AS noted in section 5, this prohibition mirrors Art 3 ECHR.
} 
provide reasons why the Article 3 threshold was not triggered, the majority's decision in respect of Article 3 leaves much to be desired.

\section{B. Setting the Threshold too High: Defining 'Legally Significant' Number}

As aforementioned, some judges found that Article 3 was not violated because not every woman who is denied an abortion in the three situations before the Court would suffer a violation of Article $3 \mathrm{ECHR}$. We argue that this reasoning sets the numerical threshold too high. In the words of Lord Mance (in relation to Article 8), it is unnecessary 'to show that a law or rule will operate incompatibly in all or most cases. It must be sufficient that it will inevitably operate incompatibility in a legally significant number of cases' (emphasis added). ${ }^{78}$ It is curious why Lord Mance did not apply the same reasoning in respect of Article 3. We prefer the approach of Lord Kerr (with whom Lord Wilson agreed), who noted that previous ECtHR jurisprudence focused on whether there is a 'real risk' of suffering treatment prohibited by Article $3 .{ }^{79}$ As illustrated in section II above, there is clearly a real risk that Northern Ireland's ban on abortion in circumstances of rape, FFA, and incest violates Article 3 ECHR.

\section{Failure to Acknowledge the Broadening Case-Law of the Court}

To date, Article 3 challenges to restrictive abortion frameworks have only been successful in two cases before the ECtHR - RR v Poland $(2011)^{67}$ and $P$ and $S \vee$ Poland (2012). ${ }^{80} R R \vee$ Poland concerned a woman whose fetus had a serious abnormality but was repeatedly denied genetic testing to confirm the diagnosis. By the time a diagnosis of fetal abnormality was confirmed, it was too late to obtain a legal abortion. $P$ and $S v$ Poland concerned a minor who became pregnant as a result of rape. She was severely mistreated at the hands of healthcare professionals, who tried to deny her access to an abortion. They also publicised her case to the media which lead to harassment from a priest and anti-abortion campaigners. Eventually, she had an abortion which in her view was done in a 'clandestine manner despite the abortion being lawful'. ${ }^{81}$ In both cases, the ECtHR found a violation of, inter alia, Article 3.

Lord Mance distinguished these cases from the one before the UKSCt on the basis that, inter alia, the cases before the ECtHR involved circumstances where the applicants were legally entitled to an abortion, but abortion was inaccessible in practice. $^{82}$ In doing so, he implied that the ECtHR would be not be willing to find a

\footnotetext{
${ }^{78}$ Para 74.

${ }^{79}$ Para 91.

${ }^{80} P$ and $S v$ Poland App No 57375/08 (ECHR, 30 October 2012).

${ }^{81} R R$ v Poland App no 27617/04 (ECHR, 26 May 2011).

${ }^{82}$ Para 97.
} 
breach of Article 3 in jurisdictions such as Northern Ireland where there was no legal right to abortion in the circumstances before the UKSCt. Consequently, he found that Northern Ireland's near-total ban on abortion did not violate Article 3 ECHR.

In our view, the legality (or illegality) of abortion is an irrelevant legal consideration in Article 3 proceedings, and thus Lord Mance erred in distinguishing $P$ and $S$ and $R R$ from the case at hand. Although the ECtHR may have found it politically less risky to find Poland's laws in violation of the ECHR, it is significant that the ECtHR did not focus on the legality of abortion within Poland. Rather, the crucial factor in the ECtHR's reasoning in both cases was that the applicants were in situations of great vulnerability. ${ }^{83}$ In $P$ and $S$, the ECtHR stated the 'cardinal importance' of the fact the applicant was only 14 , her pregnancy was a result of rape, she was in a position of 'great vulnerability', and that there was no proper regard to her 'vulnerability and young age and her own views and feelings' ${ }^{84}$ In $R R$, the ECtHR noted that the applicant: 'like any other pregnant woman in her situation, was deeply distressed by information that the foetus could be affected with some malformation. ${ }^{85}$ Moreover, the ECtHR described $R R$ 's suffering as 'aggravated' by the fact that she was legally entitled to such diagnostic tests as a matter of domestic law in the State. ${ }^{86}$ This indicates that the legality of abortion access was not the sole or necessary factor for proving a violation of Article 3. Thus, in both cases, the fact that abortion was legally provided for within Poland was ostensibly not a legal precondition for finding a violation of Article 3.

We therefore argue that Lord Mance's focus on the legality (or lack thereof) of abortion access in Northern Ireland was misplaced. As stated by Lord Kerr (with whom Lord Wilson agreed):

It cannot be correct [...] that the breach of article 3 in RR's case depended on the existence of her right to an abortion. The focus of article 3 is on the impact on the person affected by the ill-treatment alleged, not on the reasons which underlie it. ${ }^{87}$

We argue that this approach is preferable, as it fits doctrinally with the absolute nature of Article 3. In fact, we argue that the lack of legally available abortion services in the circumstances before the court if anything strengthens any claim under Article 3.

\footnotetext{
${ }^{83}$ The use of the concept of vulnerability is not without its problems. However, a detailed discussion is outside of the scope of this paper. See L Peroni and A Timmer, 'Vulnerable groups: The promise of an emerging concept in European Human Rights Convention Law' (2013) 11(4) International Journal of Constitutional Law 1056.

${ }^{84} P$ and $S$ v Poland App No 57375/08 (ECHR, 30 October 2012).

${ }^{85} R R$ v Poland App No 27617/04 (ECHR, 26 May 2011) para 159.

${ }^{86} R R$ v Poland App No 27617/04 (ECHR, 26 May 2011) para 160.

${ }^{87}$ Para 255.
} 
When a woman is denied an abortion, her suffering is made no more tolerable to her in the knowledge that the denial conformed with domestic law. Moreover, the criminalization of abortion stigmatizes a woman's actions and person, serving as a separate source of severe emotional pain. ${ }^{88}$ We strongly encourage a future court to adopt this approach and find the Northern Irish framework in violation of Article 3 for denial of abortion in cases of FFA or rape.

\section{Incorrectly Taking into Account the Purpose of the Legislation}

In finding that Northern Ireland's abortion laws did not violate Article 3 ECHR, Lord Mance referred to the purposes underlying the relevant legislation by noting that the suffering of women was the result of laws which originate 'in moral beliefs about the need to value and protect an unborn foetus'. ${ }^{89}$ Although such considerations may be relevant in respect of Article 8 when determining whether legislation is for a democratic purpose, they should not be taken into account when assessing whether Article 3 - an absolute right - has been violated. As correctly stated by Lord Kerr (with whom Lord Wilson agreed), the effect of the law:

[...] must be independently examined for its potential to qualify as treatment forbidden by article 3 . If it is found to reach that standard, it cannot be diminished or rescued from the status of article 3 ill-treatment by what might be said to be laudable motives or objectives. ${ }^{90}$

Lord Mance therefore erred in taking the motivations behind Northern Ireland's abortion law into account.

\section{E. The Possibility of Travelling Elsewhere to Avail of Abortion Services Does not Mean that Article 3 is Not Breached}

The majority was willing to find that there was no breach of Article 3 because women wishing to terminate their pregnancies could do so by travelling elsewhere. However, when discussing Article 8 , Lady Hale noted that 'relying on the possibility that [a woman] may be able to summon up the resources, mental and financial, to travel to Great Britain for an abortion if anything makes matters worse rather than better. ${ }^{, 91}$ Once again, it is questionable why this was deemed a relevant factor only in respect of Article

88 Human Rights Committee, Amanda Jane Mellet $v$ Ireland, 9 June 2016, UN Doc CCPR/C/116/D/2324/2013, para 5.4.

${ }^{89}$ Para 100.

${ }^{90}$ Para 255.

${ }^{91}$ Para 27. 
8. It would have been preferable had the majority explained why they were not applying the same considerations to both Article 8 and Article 3 in this context.

\section{F. Lack of Rigorous Analyisis}

A final criticism that joins together all the points made above is the fact that the judges paid little, if any, attention to Article 3. The brevity of the UKSC's discussion of Article 3 is particularly disappointing given the ECtHR's long-held position that:

the existence of a risk of ill-treatment in breach of Article $3[\ldots]$ must necessarily be a rigorous one in view of the absolute character of this provision and the fact that it enshrines one of the fundamental values of the democratic societies making up the Council of Europe. ${ }^{92}$

It is argued that in future cases, the court should at the very least, engage in rigorous analysis of Article 3 even if it is unwilling to find a violation in this respect.

\section{INTERNATIONAL LAW}

In the opening paragraphs of her judgment, Lady Hale appropriately noted that the ECHR has to be interpreted in light of other international treaties to which the UK is a party. Similarly, Lord Kerr (with whom Lord Wilson agreed) stated that:

[...] although the traditional and orthodox view is that courts do not apply unincorporated international treaties [...] such treaties may be relevant in a number of ways [...] namely, where the court is applying the ECHR via the HRA. ${ }^{93}$

The views of these justices reflect the well-established international law rule that treaty interpretation must take account of 'any relevant rules of international law applicable in the relations between the parties' ${ }^{94}$ This rule is frequently invoked by the ECtHR, which regularly draws upon international law to interpret the ECHR. ${ }^{141}$ However, very little reference was made to international law in this case, despite the aforementioned Justices' laudable intentions.

\footnotetext{
${ }^{92}$ Vilvarajah $v$ the United Kingdom App no 13163/87 (ECHR, 30 October 1991).

${ }_{93}$ Para 328. Unincorporated treaties refer to treaties to which the UK is a party but which have not yet been implemented into domestic law.

${ }^{94}$ Art 31(3)(c), 1969 Vienna Convention on the Law of Treaties 1155 UNTS 331.
} 
The judges had a wealth of treaties to draw upon - six in fact - which set out rights that are relevant in the abortion context. ${ }^{95}$ All of these treaties are binding on the UK, and thus 'must be performed in good faith'. ${ }^{96}$ In addition, Article27 of the Vienna Convention on the Law of Treaties (VCLT) provides that domestic law is no defence for failing to comply with international obligations. ${ }^{97}$ Although these treaties are binding at the international - rather than the domestic - level, ${ }^{98}$ the judges could have nonetheless drawn on them as a source of persuasive authority when interpreting the ECHR.

The most relevant treaty to the facts at hand was the 1966 International Covenant on Civil and Political Rights (ICCPR), yet it received scant attention in the judgment. ${ }^{99}$ The ICCPR qualifies as a 'relevant rule of international law'100 that informs the interpretation of the ECHR because ICCPR and the ECHR both protect rights that are primarily civil and political in nature, and they are inspired by the Universal Declaration of Human Rights, as well as ideals of peace, freedom, and justice. ${ }^{101}$ Indeed, the ECtHR has also been more receptive to the ICCPR than to any other treaty in its decisions. ${ }^{102}$ Of particular importance to the case at hand is the ICCPR's monitoring body, the Human Rights Committee (HRC), which has delivered its views on the compatibility of strict abortion regimes with the ICCPR. Although Lord Mance stated that the HRC's

\footnotetext{
${ }^{95}$ The UK is a party to the following treaties which were relevant to the subject matter before the UKSCt: 1984 Convention against Torture 1465 UNTS 85; 1966 International Covenant on Economic, Social, and Cultural Rights; 1966 International Covenant on Civil and Political Rights 999 UNTS 171; 1989 Convention on the Rights of the Child 1577 UNTS 3; 1979 Convention on the Elimination of all forms of Discrimination against Women 1249 UNTS 13; 2008 Convention on the Rights of Persons with Disabilities 2515 UNTS 3.

${ }^{96}$ Office of the High Commissioner for Human Rights, 'Ratification of 18 International Human Rights Treaties', available at http://indicators.ohchr.org

${ }_{97}^{97}$ Art 27, 1969 Vienna Convention on the Law of Treaties 1155 UNTS 331.

${ }^{98}$ The UK is a party to these treaties because they have ratified and/or acceded to. This means that under international law, the UK is responsible for violations of these treaties. However, in order for the treaties to be binding domestically (i.e. invoked as binding law before a court), they must be transposed into domestic law by a domestic implementing legislative act. None of these 6 treaties have been transposed in such a manner. Therefore in a domestic court, these treaties are of persuasive authority only.

99 The ICCPR and the views of the HRC were cited by Lord Kerr (with whom Lord Wilson agreed) in para 229 when listing the arguments made by the applicant. However, in para 230, he stated that it was unnecessary for him to discuss international law in light of his views that Northern Ireland's law was in violation of the HRC. He noted that it was 'sufficient to record that the conclusion that the current law in Northern Ireland on abortion, as it affects fatal foetal abnormality and pregnancy as a result of rape and incest is incompatible with the Convention, is in harmony with many [provisions of international law].' He also noted that he expressed no views on the views of the HRC because the status of those decisions and their relevance in domestic proceedings such as these are far from straightforward subjects.' Lord Mance referred to the ICCPR and the views of the HRC in para 101, but (incorrectly, in our view) stated that they were not applicable to the present case in para 102. This issue is analysed in more detail below.

${ }_{100}^{10}$ Art 31(3)(c) 1969 Vienna Convention on the Law of Treaties 1155 UNTS 331.

101 Preambles to the ECHR and ICCPR.

102 M Forowicz, The Reception of International Law in the European Court of Human Rights, (Cambridge University Press 2010), 175.
} 
views are 'not authorities as to the position under the ECHR' ${ }^{103}$ we argue that the views of the HRC are persuasive (albeit non-binding) because the HRC has been mandated to provide 'authoritative'104 and 'determinative'105 interpretations of the ICCPR; ${ }^{106}$ and members of the HRC are persons of high moral character and recognized competence in the field of human rights. ${ }^{107}$ Most, if not all of them, are experts in international law, and thus their views are a subsidiary source of international law. ${ }^{108}$ Finally, the ECtHR has frequently relied upon the views of the HRC in interpreting the $\mathrm{ECHR} .{ }^{109}$

Two recent complaints before the HRC dealt with similar circumstances to those before the UKSCt, and thus should have been engaged with by the UKSCt. ${ }^{110}$ The complaints of Mellet $v$ Ireland (June 2016) ) $^{111}$ and Whelan $v$ Ireland (June 2017) ${ }^{112}$ both concerned women who were carrying fetuses with a fatal abnormality. Similar to Northern Ireland, Irish law does not provide for abortion in cases of fatal fetal abnormality. ${ }^{113}$ The women thus had to travel to the UK for a termination, but they were not provided with information on accessing abortion services in the UK and faced significant financial and practical travelling difficulties. They both had to leave the fetal remains in the UK which were subsequently delivered to them. Neither woman received any support upon returning to Ireland while suffering from complicated grief and feelings

${ }_{104}^{103}$ Para 102. Protocol to the International Covenant on Civil and Political Rights', 25 June 2009, UN Doc CCPR/C/GC/33 para 14.

105 Human Rights Committee, General Comment 33, 'Obligations of States parties under the Optional Protocol to the International Covenant on Civil and Political Rights', 25 June 2009, UN Doc CCPR/C/GC/33 para 11.

106 JE Alvarez has described them as 'quasi-judicial'. See JE Alvarez, International Organisations as LawMakers (Oxford University Press 2006), Chapter 6.

107 Art 28, 1966 International Covenant on Civil and Political Rights 999 UNTS 171.

108،Human Rights Committee: Membership' http://www.ohchr.org/EN/HRBodies/CCPR/Pages/Membership.aspx accessed 22 February 2018; Art $38(1)(d), 1946$ Statute of the International Court of Justice.

${ }^{109}$ Py v France App no 66289/01 (ECHR, 1 November 2005); TH and SH v Finland App No $19823 / 92$ (ECHR, 9 February 1993); Kurt v Turkey App No 15/1997/799/1002 (ECHR, 25 May 1998); Mamatkulov and Abdurasulovic v Turkey App Nos 46827/99, 46951/99 (ECHR, 6 February 2003); Mamatkulov and Askarov v Turkey App Nos 46827/99, $46951 / 99$ (ECHR, 4 February 2005).

${ }^{110}$ Complaints can be brought to the HRC against State Parties to First Optional Protocol of the ICCPR. The UK is not a party to this protocol. However the views of the HRC should be viewed as persuasive because they are authoritative interpretations of the ICCPR, to which the UK is bound.

${ }_{111}$ HRC, Amanda Jane Mellet $v$ Ireland, 9 June 2016, UN Doc CCPR/C/116/D/2324/2013.

112 HRC, Siobhán Whelan v Ireland, 12 June 2017, UN Doc CCPR/C/119/D/2425/2014.

113 Proposed legislation is currently before the Irish Parliament which would provide access in such cases if accepted. See: Abortion Bill passes to next stage by 102 votes to 12 with seven abstentions (Irish Times, 23 October 2018) available at https://www.irishtimes.com/news/politics/abortion-bill-passes-tonext-stage-by-102-votes-to-12-with-seven-abstentions-1.3673079 It has recently been considered at Committee stage, see 'Committee finishes considering abortion legislation' (RTE News, $8^{\text {th }}$ November 2018) https://www.rte.ie/news/politics/2018/1108/1009600-abortion-legislation-committee/ 
of isolation. In respect of both women, the HRC found that Ireland violated Arts $7,{ }^{114}$ $17,{ }^{115}$ and 26 of the ICCPR. ${ }^{116}$ Our focus is on the Article7 claim, because Article7 mirrors the wording of Article 3 ECHR. We argue that the UKSCt should have taken the views of the HRC into account because of (i) their persuasive authority, as outlined above; and (ii) the fact that the HRC dealt with abortion and FFA, which was an issue before the UKSCt.

Lord Mance succinctly distinguished the views of the HRC in Mellet and Whelan from the case before the UKSCt on the basis that alleged ill- treatment must reach a significant severity before it triggers Article $3 .{ }^{117}$ In doing so, he implied that treatment does not need to be of a significant severity before falling under Article7 of the ICCPR and thus the HRC's views on Article 7 were irrelevant. We respectfully disagree with this interpretation. The HRC engaged in a detailed analysis of the conditions facing both complainants which shows that, like the ECtHR, the HRC carefully scrutinises the facts at hand to determine whether there has been a breach of Article 7. Indeed, Lord Mance accepted in his judgment that they 'focus intensely on the particular facts'. ${ }^{118}$ The HRC held that the complainants' physical and mental anguish had been exacerbated by: (i) not being able to continue receiving medical care and health insurance coverage for treatment from the Irish health care system; (ii) the need to choose between continuing a non-viable pregnancy or travelling to another country while carrying a dying fetus, at personal expense and separated from family support, and to return while not fully recovered; (iii) the shame and stigma associated with the criminalization of abortion of a fatally ill fetus; (iv) the fact of having to leave the fetus' remains behind; and (v) the State's refusal to provide necessary and appropriate post-abortion and bereavement care. The HRC found that many of these experiences could have been avoided if the complainants had not been prohibited from terminating their pregnancies in the familiar environment of their own State. It considered that the complainants' suffering was further aggravated by the obstacles faced in receiving needed information about appropriate medical options from known and trusted medical providers. Thus, the HRC engaged in a close scrutiny of whether the circumstances met the Article 7 threshold.

\footnotetext{
114 This article provides that 'No one shall be subjected to torture or to cruel, inhuman or degrading treatment or punishment. In particular, no one shall be subjected without his free consent to medical or scientific experimentation.'

${ }^{115}$ This article provides that '(i) No one shall be subjected to arbitrary or unlawful interference with his privacy, family, home or correspondence, nor to unlawful attacks on his honour and reputation. (ii)Everyone has the right to the protection of the law against such interference or attacks.'

116 This article provides that 'All persons are equal before the law and are entitled without any discrimination to the equal protection of the law. In this respect, the law shall prohibit any discrimination and guarantee to all persons equal and effective protection against discrimination on any ground such as race, colour, sex, language, religion, political or other opinion, national or social origin, property, birth or other status.'

117 Para 102.

${ }^{118}$ Para 102.
} 
This is very similar to the approach taken by the ECtHR in interpreting Article 3 of the ECHR. Therefore, we argue that the HRC and ECtHR's approach can be readily compared, and the HRC's views should have been considered in the UKSCt's decision.

As a final note, it should be stated that the UKSCt's treatment of international law is not wholly without merit. The UKSCt is to be commended for correctly identifying that there is no consensus in international law over whether there is a right to an abortion in cases of serious fetal abnormality. As noted by Lady Hale and Lord Kerr (with whom Lord Wilson agreed), although the Committee on the Elimination of Discrimination against Women has recommended to the UK to legalise abortion 'at least' where there is a threat to the pregnant woman's physical or mental health; rape or incest; and severe foetal impairment, including FFA; ${ }^{119}$ it has reconciled its views with that of the UN Committee on the Right of Persons with Disabilities that this should be done 'without perpetuating stereotypes towards persons with disabilities and ensuring appropriate and ongoing support, social and financial, for women who decide to carry such pregnancies to term. ${ }^{120}$ Consequently we argue that in finding that Article 3 did not provide a right to abortion in cases of serious fetal abnormality, the UKSCt appropriately aligned itself with international law.

\section{CONCLUSION}

Many aspects of the UKSCt decision are to be welcomed. It is the first case to consider substantive laws on abortion in Northern Ireland, and to make a finding, albeit in obiter terms, that Northern Irish law in so far as it prohibits abortion in cases of rape, incest and fatal fetal abnormality is a violation of Article $8 \mathrm{ECHR}$. Some judges were also willing to find violations of a breach of Article 3 in respect of the same circumstances. When read alongside the recent developments such as the Irish referendum repealing its constitutional ban on abortion, ${ }^{121}$ a report from the UN CEDAW Committee determining that Northern Ireland's current law on abortion leads to grave and systematic violations of international human rights law, ${ }^{122}$ and the debate on

\footnotetext{
${ }^{119}$ Para 133.

120 Para 133.

${ }^{121}$ For a discussion of this referendum see: A McMahon and B Ní Ghráinne, 'After the Eighth: Ireland, Abortion and International Law' available at https://papers.ssrn.com/sol3/papers.cfm?abstract id=3256317

${ }^{122}$ Report of the inquiry concerning the United Kingdom of Great Britain and Northern Ireland under Art 8 of the Optional Protocol to the Convention on the Elimination of All Forms of Discrimination against Women CEDAW/C/OP.8/GBR/1 available at https://tbinternet.ohchr.org/ layouts/treatybodyexternal/Download.aspx?symbolno=CEDAW\%2fC\%2fOP. 8\%2fGBR\%2f1\&Lang=en
} 
decriminalization of abortion in Westminster, it adds to the wider political landscape of mounting pressure calling for reform of this area of law. ${ }^{123}$ Indeed, the UKSCt's encouragement of future litigation is likely to lead to a declaration that Northern Ireland's law is incompatible with the ECHR. This will put further pressure on the Northern Irish Assembly to enact legislative change.

We argue that the UKSCt's finding in respect of Article 8 ECHR was appropriate. Nonetheless, in considering future challenges, courts should be encouraged to engage more deeply with Article $3 \mathrm{ECHR}$ and refer to relevant international law. A violation under Article 3 is one of the severest violations within human rights law and would send a clear message to the Northern Ireland Assembly and the UK government on the need to amend the existing framework. Finding a breach of Article 3 alongside Article 8 ECHR would be a direct acknowledgement of women's suffering in this context, would provide a truer reflection of the level of incompatibility that exists between Northern Irish law and international law and practically, would add to the mounting pressure on Northern Ireland to change its laws.

${ }^{123}$ K McNeilly, F Bloomer and C Pierson, 'The Supreme Court's decision on Northern Ireland's abortion law - what now?' available at http://blogs.Ise.ac.uk/politicsandpolicy/supreme-court-on-ni-abortion-law/ . 